\title{
Of Mice and Men, de John Steinbeck
}

\author{
Ana Lúcia da Silva Kfouri
}

\begin{abstract}
Resumo: O objetivo deste trabalho é propor uma tradução para o português brasileiro do primeiro trecho da obra literária Of mice and men de John Steinbeck. O excerto escolhido contém a voz do narrador, em linguagem norma culta padrão do inglês norte-americano, em oposição à voz dos dois protagonistas da história, Lennie e George, concebida como variante dialetal contento traços de oralidade, muitas vezes marcada por vocábulos informais e/ou uso da ortografia e sintaxe fora da norma culta padrão. O objetivo da tradução foi tentar manter no português brasileiro a oposição entre a vOz, em norma culta padrão, do narrador, e as marcas de oralidade das falas das personagens de modo a tentar manter a verossimilhança com o discurso oral dos falantes do português brasileiro, assim como a verossimilhança interna com a oralidade característica das falas das personagens.
\end{abstract}

Palavras-chave: Literatura. Tradução. Marcas de oralidade. John Steinbeck.

\begin{abstract}
The aim of this paper is to propose a translation into Brazilian Portuguese of the first excerpt in John Steinbeck's literary work $O f$ mice and men. The excerpt to be translated contains the voice of the narrator, in standard American English, as opposed to the voice of the two main characters in the story, Lennie and George, conceived as a dialectal variant with features of orality, often marked by informal words and/or use of non-standard spelling and syntax. The translation aimed at attempting to maintain in Brazilian Portuguese the opposition between the narrator's voice, in standard American English, and the orality marks of the characters' speeches in an attempt to keep verisimilitude with the oral speech of Brazilian Portuguese speakers, as well as the internal verisimilitude with the orality contained in the characters' speeches.
\end{abstract}

Keywords: Literature. Translation. Orality marks. John Steinbeck.

\section{Sobre Ratos e Homens}

A poucas milhas ao sul de Soledad, o Rio Salinas segue próximo à encosta das colinas, correndo profundo e verde. Além disso, a água é morna, pois corre cristalina sobre 
as areias amareladas pela luz do sol antes de chegar a um lago estreito. Ao lado do rio, as encostas do sopés das colinas em tom dourado se curvam para as montanhas Gabilan, imponentes e rochosas, mas no vale do rio, a água se alinha com árvores - salgueiros frondosos e verdes a cada primavera, carregando em suas folhas mais rentes ao solo os restos da inundação do inverno, e sicômoros com ramos manchados e esbranquiçados e galhos que se curvam sobre o lago. $\mathrm{Na}$ arenosa margem do rio abaixo das árvores, as folhas repousam em uma tão profunda e seca camada que um lagarto desliza ao tentar correr entre elas. Coelhos aparecem dos arbustos para repousarem na areia ao anoitecer, e as superfícies úmidas ficam cobertas com as pegadas noturnas dos guaxinins, e com as pegadas espalhadas do cães dos ranchos, e com o rastro das pegadas bifurcadas dos cervos que chegam para beber água no escuro da noite.

Existe uma picada por entre os salgueiros e entre os sicômoros, um caminho de terra batida aberto por meninos vindos dos ranchos para nadar no lago profundo, e batido por andarilhos que cansados vêm pela rodovia à noite para acamparem junto à água. Em frente a um galho do sicômoro gigante caído no chão, há um monte de cinzas acumuladas de muitos fogareiros; o galho está desgastado por homens que já se sentaram lá.

A noite, após um dia quente, trouxe um ventinho que dançava por entre as folhas. A sombra escalava as colinas até o topo. Nas margens arenosas, os coelhos repousavam tão silenciosos como pequenas pedras cinzentas lá esculpidas. E, da direção da rodovia estadual, ouviu-se o som de passos crepitando nas folhas dos sicômoros. Os coelhos correram à procura de abrigo. Uma garça-real levantou voo, batendo no lago. Por um momento, o lugar estava sem vida, e, então, dois homens surgiram da picada e chegaram ao amplo local junto ao lago verde.

Eles haviam caminhado em fila indiana ao longo da picada e, na clareira, permaneceram um atrás do outro. Ambos vestiam calças rancheiras e jaquetas jeans com botões de metal. Ambos usavam um chapéu preto disforme e ambos carregavam um cobertor apertado em um rolo que pendia pelos ombros. O primeiro homem era pequeno e ágil, de rosto moreno, olhos cansados e expressivos, características marcantes. Toda sua figura era bem definida: mãos pequenas e fortes, braços delgados, nariz fino e ossudo. Atrás dele vinha o oposto, um homem enorme, rosto sem formato definido, de olhos grandes e pálidos, com ombros largos e ligeiramente caídos. Ele caminhava a passos pesados, arrastando os pés, da mesma forma com que um urso arrasta as patas. Seus braços não acompanhavam o ritmo do seu caminhar, mas pendiam livremente.

O primeiro homem logo parou na clareira e o homem que o seguia quase o atropelou. Ele tirou o chapéu e limpou o suor com o dedo indicador, jogando longe gotículas de umidade. Seu enorme companheiro largou o cobertor e se jogou ao chão, sorvendo água da superfície do lago. Ele bebia em goles fartos, bufando na água como um cavalo. O homem pequeno parou ao seu lado, nervoso.

- Lennie! - disse ele com rispidez. - Lennie, por Deus, num bebe muito.

Lennie continuava a chafurdar no lago. O homem pequeno se inclinou e o chacoalhou pelo ombro. 
- Lennie. Cê vai ficar doente que nem ficou ontem de noite.

Lennie afundou toda a cabeça na água, com chapéu e tudo, e, então, se sentou à margem do lago com seu chapéu pingando água, que corria pelas suas costas molhando a jaqueta azul.

- Tá boa, - disse ele. - Vai, bebe um pouco, George. Bebe um golão. - Ele falava com alegria.

George desfez sua trouxa e com cuidado colocou-a no chão.

- Num tenho certeza que é água boa, - disse ele. - Parece meia espumosa.

Lennie batia levemente a superfície da água com sua enorme pata e sacudia os dedos de forma que a água salpicava no ar. Anéis de água se espalhavam pela superfície e quando alcançavam a outra margem, batiam e voltavam. Lennie observava-os ir e vir.

- Olha, George, olha o qu'eu fiz.

George joelhou-se à beira do lago e bebeu da água com as mãos em goles rápidos.

- Me parece boa, - admitiu. - Mas acho que num é corrente. Cê nunca deve de beber quando a água num tá correndo, Lennie, - disse ele desanimado. - Cê ia até beber água de sarjeta se tava cum sede.

Jogou um pouco de água no rosto e o esfregou com as mãos, abaixo do queixo e em volta do pescoço. Recolocou seu chapéu, afastou-se da beira da água, encolheu os joelhos e os enlaçou. Lennie, que o observava, imitou exatamente o que George fazia. Afastou-se da água, encolheu os joelhos e os enlaçou, olhando para George para ver se havia feito tudo certo. Abaixou o chapéu um pouco abaixo dos olhos, do mesmo modo com que fizera George.

George olhava sério para a água. Seus olhos estavam vermelhos pelo brilho do sol.

- A gente já podia muito bem tá perto do rancho se aquele idiota do motorista do ônibus sabia o que tava falando. 'Só mais um trechinho na estrada,' ele diz. 'Só um tiquinho a mais'. Malditas quatro milha, isso é o que foi! Num queria parar no rancho, isso sim. Muita preguiça pra encostar. Acho que nem é bom pra parar em Soledad, isso sim. Chuta a gente e ainda fala, 'Só mais um trechinho na estrada'. Aposto que era muito mais que quatro milha. Maldito calor. - George vociferou.

Lennie o olhava com cuidado.

- George?

- Quê? Que que cê quer?

- Aonde a gente tá indo, George?

O homem pequeno puxou a borda do chapéu e olhou para Lennie com uma careta.

- Então cê já esqueceu, né? Preciso te falar de novo, né? Jesus! Seu idiota!

- Esqueci, - disse Lennie baixinho. - Tentei num esquecer. Juro por Deus que tentei, George.

-Tá, tá. Vou te falar de novo. Num tenho nada pra fazer mesmo, né? Posso muito bem ficar o tempo todo te falando as coisa e você esquece tudo de novo e eu falo tudo de novo. 
- Tentei e tentei, - disse Lennie, - mas num funcionou. Eu lembro tudo dos coelho, George.

- Pro inferno c'os coelho. É só o que tu consegue lembrar é dos coelho. Tá. Então presta atenção que agora cê vai ter que lembrar senão a gente vai ter problema. Cê lembra de sentar lá na sarjeta na rua Howard e olhar lá no quadro negro?

Lennie abriu um sorriso radiante.

- Nossa, claro, George, eu lembro que ... mas ... que que a gente fez? Lembro que umas menina veio e cê diz... cê fala...

- Pro diabo o que eu falo. Cê lembra da gente indo lá no Murray e Ready e eles dão pra gente cartera de trabalho e bilhete de ônibus?

- Ah, é verdade, George. Lembro agora. - Rapidamente deslizou as mãos pelos bolsos da jaqueta. Então disse gentilmente:

- George... Num tenho a minha. Devo de ter perdido.

Olhava para o chão em desespero.

- Cê nunca ficou com ela, seu imbecil idiota. Eu tenho as duas aqui comigo. Cê acha que eu ia te deixar cê carregar tua cartera?

Lennie sorriu aliviado.

- Eu... eu achei que pus no meu bolso. - Deslizou a mão pelo bolso novamente.

George o olhava com seriedade.

- Que que cê tem aí no bolso?

- Num tem nada no meu bolso, - Lennie retrucou.

- Ah tá que num tem. Cê tem na mão. Que que cê tem aí na mão, escondendo?

- Num tenho nada, George. Sério.

- Vai, me dá aqui.

Lennie mantinha a mão fechada bem distante de George.

-É só um rato, George.

- Um rato? Tá vivo?

- Uh, uh. Só um rato morto, George. Num matei ele. Sério! Eu achei. Já achei morto.

- Me dá aqui, - disse George.

- Ah, George, deixa eu ficar com ele.

- Me dá aqui?

Lennie esticou a mão fechada bem devagar. George arrancou o rato e o atirou para o outro lado do lago por entre os arbustos.

- Mas pra que que cê quer um rato morto?

- Eu podia fazer carinho nele enquanto a gente andava, - respondeu Lennie.

- Bom, cê num vai fazer carinho em rato nenhum enquanto anda comigo. Cê lembra aonde a gente tá indo agora?

Lennie o olhava atônito e, envergonhado, escondeu o rosto contra os joelhos. 
- Esqueci de novo.

- Meu Deus! - disse George com resignação. - Bom, olha, a gente tá indo pra um rancho que nem aquele que a gente veio do norte.

- Do norte?

- De Weed.

- Ah, claro. Lembro. De Weed.

- Esse rancho que a gente tá indo é logo ali uns metro. A gente vai lá e fala com o chefe. Agora, olha, eu vou dar pra ele as cartera de trabalho e cê num vai falar nenhuma palavra. Cê só fica lá parado e num fala nada. Se ele descobre que cê é um maluco idiota, a gente num pega o trabalho, mas se ele vê cê trabalhar antes de ouvi cê falar, então tá tudo bem. Entendeu?

- Claro, George. Claro que entendi.

- Tá. Agora, quando a gente for ver o chefe, que que cê vai fazer?

- Eu... eu, - Lennie pensava. Espremeu o rosto para pensar. - Eu... num vou falar nada. Só vou ficar lá parado.

- Bom menino. Ótimo. Repete isso duas, três vez daí certeza que cê num vai esquecer.

Lennie falava consigo mesmo com calma: - Num vou falar nada ... num vou falar nada ... num vou falar nada.

- Tá, - disse George. - E também num vai fazer nada errado que nem fez lá em Weed.

Lennie estava intrigado.

- Que nem eu fiz em Weed?

- Ah, então esqueceu aquilo também? Tá, nem vou te lembrar, vai que faz de novo.

Lennie entendeu e seu rosto de iluminou.

- Eles correro ca gente de Weed, - gritou em triunfo.

- Correro o cacete, - disse George furioso. - A gente correu. Eles tava procurando a gente, mas num pegou.

Lennie dava risadinhas de alegria.

- Num esqueci isso, não, pode apostar.

George deitou-se na areia e cruzou as mãos sob a cabeça, e Lennie o imitou, levantando a cabeça para ver se o imitava corretamente.

- Deus, cê é só problema, - comentou George. - Eu podia me virar tão bem sozinho se num tinha você na minha cola, eu podia viver numa boa e até ter namorada.

Lennie permaneceu quieto por uns instantes e, então, disse com entusiasmo: - A gente vai trabalhar num rancho, George.

- Vamo. Cê entendeu isso. Mas a gente vai dormir aqui porque eu tenho um motivo.

O dia passava rapidamente. Somente o topo das montanhas Gabilan ardia com a luz do sol que se punha no vale. Uma cobra d'água deslizava no lago, a cabeça ereta 
como um pequeno periscópio. Os juncos se agitavam na correnteza. Ao longe na direção da rodovia, um homem gritou algo e outro homem respondeu. Os galhos do sicômoro rangiam por causa do vento leve que logo passou.

- George, por que a gente num vai pro rancho e janta lá? Tem janta no rancho.

George se virou de lado.

- Num tenho que explicar nada pra ti. Gosto daqui. Amanhã a gente vai trabalhar. Eu vi umas máquina colhedora pra lá. Quer dizer que a gente vai carregar saco, abrir valeta. Hoje a gente vai deitar aqui e olhar pro céu. Gosto disso.

Lennie se ajoelhou e olhou para George.

- A gente num vai jantar?

- Claro que vai, se tu for lá e catar uns galho seco do salguero. Tenho trêis lata de fejão na minha troxa. Cê faz o fogo. Te dou um fósfro e cê cata os galho. Daí a gente esquenta o fejão e come.

Lennie retrucou: - Gosto de fejão com ketchup.

- Bom, num tem ketchup. Vai e cata as madera. E num apronta por aí. Vai ficar noite $\log$.

Lennie se pôs em pé e desapareceu por entre os arbustos. George permaneceu deitado onde estava, assobiando baixinho para si mesmo. Havia barulho de água agitada no rio na direção que Lennie fora. George parou de assobiar e prestou atenção.

- Pobre coitado, - murmurou e, então, continuou assobiando.

Logo depois Lennie reapareceu dos arbustos. Carregava um pequeno graveto de salgueiro na mão. George se sentou.

- Tá bom, - disse ele bruscamente, - me dá esse rato!

Lennie fez uma encenação de inocência.

- Que rato, George? Num tenho nenhum rato.

George esticou a mão.

- Vai. Me dá aqui. Cê num vai me enganar.

Lennie hesitou, afastou-se um pouco, olhou ansioso para os arbustos como se contemplasse sua corrida em fuga. George disse com frieza:

- Cê vai me dar esse rato ou vou ter que te socar?

- Te dá o quê, George?

- Cê sabe muito bem. Quero o rato.

Lennie relutante buscou seu bolso. Sua voz era um pouco trêmula.

- Num sei por que num posso ficar com ele. Num é de ninguém. Num roubei. Só achei deitado no caminho.

George mantinha a mão esticada com autoridade. Devagar, assim como um cãozinho que não quer devolver a bola ao seu dono, Lennie aproximou-se, afastou-se, aproximou-se novamente. George estalou os dedos vigorosamente, e ao ouvir o som, Lennie deitou o rato na mão de George. 
- Num tava fazendo nada errado com ele, George. Só tava fazendo carinho.

George se levantou e atirou o rato tão longe quanto conseguiu por entre os arbustos e, então, parou à beira do lago e lavou as mãos.

- Seu grande idiota. Cê acha que eu num vi que seus pé tava molhado de quando cê foi no rio pra pegar ele?

George ouviu Lennie choramingar e se virou.

- Choramingando que nem bebê? Jesus! Um baita homem que nem tu.

Os lábios de Lennie tremiam e lágrimas brotavam em seus olhos.

- Ah, Lennie!

George pousou a mão sobre o ombro de Lennie.

- Num tô tirando ele de maldade. Esse rato tá morto, Lennie, e cê ainda quebrou ele de fazer carinho. Cê arranja outro rato vivo e eu deixo cê ficar com ele um pouco.

Lennie sentou-se no chão e abaixou a cabeça desanimado.

- Num sei onde tem outro rato. Lembro que uma dona dava eles pra mim sempre que ela tinha um. Mas a dona num tá mais aqui.

George zombou de Lennie.

- Dona, é? Nem lembra mais quem ela era. Era tua tia Clara. E ela parou de te dar rato. Cê sempre matava eles.

Lennie o olhou com tristeza.

- Eles era tão pequeno, - disse em tom de desculpas. - Eu fazia carinho neles e logo eles mordia meus dedo e eu apertava a cabeça deles um pouquinho e dai eles morria, porque era bem pequeno.

- Eu queria que a gente tinha logo os coelho, George. Eles num é tão pequeno.

- Pro inferno c’os coelho. E num dá pra confiar em você com nenhum rato vivo. Tua tia Clara te dá rato de borracha e cê num fazia nada com ele.

- Num era bom de fazer carinho, - argumentou Lennie.

O reflexo avermelhado do pôr do sol escalava as montanhas e o crepúsculo descia ao vale, uma semiescuridão se aproximava por entre os salgueiros e os sicômoros. Uma carpa grande saltou à superfície do lago, engoliu ar e, então, mergulhou desaparecendo na água, deixando rastros de anéis no lago. No alto, as folhas se agitavam novamente e pequenos flocos de algodão do salgueiro planavam e pousavam na superfície da água.

- Cê vai pegar a madera?, - ordenou George. - Tem bastante lá pra cima atrás daquele sicômoro. Madera de enchente. Vai lá e pega.

Lennie foi até atrás da árvore e trouxe muitas folhas secas e gravetos. Ele os jogou em um monte de cinzas e voltou para apanhar mais e mais. Já era quase noite. Uma pomba bateu asas próximo à água fazendo barulho. George se dirigiu ao monte de gravetos e folhas e ateou fogo nas folhas secas. A chama crepitava entre os gravetos e o fogo começou a crescer. George desfez sua trouxa e tirou as três latas de feijão, colocando-as sobre o fogo, bem perto do calor da chama, porém o suficiente para não encostar. 
- Tem bastante fejão pra quatro, - comentou George.

Lennie o observava do outro lado da fogueira. Disse então calmamente: - Gosto cum ketchup.

- Saco, num tem, - explodiu George. - Qualquer coisa que num tem é o que cê quer. Deus do céu, se eu tava sozinho eu vivia bem melhor. Ia ter emprego e trabalho e nenhum problema. Nenhuma confusão mesmo! E quando vinha o fim do mês eu podia pegar meus cinquenta paus e ir pra cidade e compra o que queria. Nossa! Eu podia ficar em um putero a noite toda. Podia comer em qualquer lugar que eu queria, hotel ou qualquer lugar e pedir qualquer porcaria que eu queria. E podia fazer tudo isso todo mês. Comprar um litro de uísque ou até ir pra um bilhar e jogar carta ou sinuca.

Lennie, de joelhos, olhava para George por cima do fogo, com o rosto aterrorizado.

- E que que eu tenho, - George continuou furioso. - Tenho você! Cê num consegue ficar num emprego e me faz perder meu emprego também. Fica me atropelando por todo lugar o tempo todo. E num é o pior. Tu se mete em encrenca. Faz tudo errado e eu tenho que te livrar. - Sua voz aumentou, estava quase gritando. - Seu louco, filho da puta. Cê fica me metendo em encrenca o tempo todo. - Ele imitou gestos e maneirismos de garotinhas quando ficam imitando umas às outras. - Só queria sentir o vestido da moça, só queria passar a mão que nem num rato. Ah tá, como que ela ia saber que tu só queria sentir o vestido? Ela se joga pra trás e tu segura no vestido que nem num rato. Ela grita e a gente tem que esconder numa vala de irrigação c'os cara procurando a gente e a gente tem que sair de fininho no escuro e ir embora. Toda hora alguma coisa que nem essa, toda hora! Queria enfiar você numa gaiola com um milhão de rato pra tu se diverti bem. - Sua raiva de repente arrefeceu. Ele olhou por cima do fogo para o rosto angustiado de Lennie, e, então, desviou o olhar para as chamas, envergonhado.

Estava escuro agora, mas o fogo iluminava os troncos das árvores e os galhos curvos acima deles. Lennie engatinhou bem devagar e com muito cuidado contornou a fogueira aproximando-se de George. Sentou-se sobre os calcanhares. George virou as latas de feijão de modo que o outro lado agora estava para o fogo. Fingiu não perceber a presença de Lennie tão próximo.

- George, - disse bem suavemente. Sem resposta. - George!

- Que que cê quer?

- Eu tava só brincando, George. Eu num quero ketchup. Eu num ia nem querer se tinha bem daqui do meu lado.

- Se tinha aqui cê podia comer.

- Mas eu num ia nem comer nada, George. Deixava tudo pra você. Cê podia cobrir todo seu fejão de ketchup e eu num ia nem tocar.

George matinha o semblante sério, olhando para o fogo.

- Quando penso que podia tá numa boa sem ter você fico louco. Nunca tenho paz.

Lennie mantinha-se de joelhos. Desviou o olhar para a escuridão, do outro lado do rio. 
- George, cê quer, eu vou embora e deixo você.

$-\mathrm{E}$ aonde cê ia?

- Ah, eu ia. Eu ia embora lá pras colina. Achava alguma toca.

- Ah, é? E ia comer o quê? Cê num tem cabeça nem pra catar alguma coisa pra comer.

- Eu achava as coisa, George. Num preciso de comida boa cum ketchup. Eu deitava no sol e ninguém me machucava. E se eu achava um rato podia ficar com ele. Ninguém ia tirar ele de mim.

George levantou os olhos rapidamente, procurando por Lennie.

- Eu fui ruim, né?

- Se você num me quer, eu vou lá pras colina e acho uma toca. Posso ir embora qualquer hora.

- Não! Olha, eu tava brincando, Lennie. Quero que cê fica aqui comigo. O problema c'os rato é que tu sempre mata eles. - George fez uma pausa. - Vou te falar o que vou fazer, Lennie. Primeira chance e vou te dar um cachorrinho. Talvez cê num mata ele. Vai ser melhor que rato. E cê pode fazer carinho mais forte.

Lennie evitou cair na conversa. Percebeu que tinha uma vantagem.

- Se você num me quer, cê só precisa me falar, e eu vou lá pra cima nas colinas, lá mesmo naquelas colina, e fico sozinho. E ninguém vai roubar os rato de mim.

George respondeu: - Eu quero que cê fica aqui comigo, Lennie. Meu Deus! Alguém ia dar um tiro em você pensando que cê era um coiote, se tu fica sozinho. Não, cê fica comigo. Tua tia Clara num ia gostar de ver cê sozinho por aí mesmo se ela tá morta.

Habilmente Lennie retrucou: - Me conta que nem cê já contou antes.

- Contar o quê?

- Dos coelho.

George gritou: - Cê num vai conseguir nada comigo.

Lennie suplicava: - Ah, vai, George. Me conta. Por favor, George. Que nem cê já faz antes.

- Tu se diverte com isso, né? Tá bom. Vou contar e daí a gente janta...

A voz de George tornou-se grave. Ele repetia as palavras em ritmo como se já as tivera dito antes.

- Caras como a gente, que trabalha em rancho, são os cara mais sozinho que tem no mundo. Eles num tem família. Eles num são de lugar nenhum. Eles chega num rancho e trabalha pra ganhar o dinheiro e daí vai pra cidade pra torrar o que ganhou, e daí a primera coisa que cê sabe deles é que eles vão logo pra outro rancho. Eles num tem nada pra pensar de futuro.

Lennie estava exultante.

- Isso, isso! Agora conta como é com a gente.

George continuou. 
- Com a gente num é assim. A gente tem futuro. A gente tem alguém pra conversar que liga pra gente. A gente num tem que sentar num bar e gastar toda a grana porque a gente tem lugar pra ir. Se aqueles outros cara vai preso eles podem até apodrecer lá que ninguém liga pra eles. Mas não a gente.

Lennie, num ímpeto, interrompeu: - Mas não a gente! E sabe por quê? Porque.... porque eu tenho você pra cuidar de mim e você tem eu pra cuidar de você, por isso. - Lennie ria alto de contentamento. - Agora continua você, George!

- Cê já sabe tudo de cabeça. Conta você mesmo.

- Não, você. Eu esqueço algumas coisas. Me conta como é que vai ser.

- Tá. Um dia, a gente vai ganhar dinheiro junto e a gente vai ter uma casinha e umas terra e uma vaca e alguns porco e...

- E viver da terra!, - Lennie gritou. - E ter coelho. Vai, George, continua. Conta o que a gente vai ter no jardim e dos coelho nas gaiola e da chuva no inverno e do fogão e como a nata do leite é tão grossa que quase que dá pra cortar. Fala disso, George!

- Por que cê num fala você mesmo? Já sabe tudo.

- Não ... você fala. Num é igual se eu contar. Vai ... George. Como que eu vou cuidar dos coelho.

- Bom, - disse George, - a gente vai ter um pomar grande e uma cabana dos coelho e galinheiro. E quando a chuva vem no inverno, a gente só vai mandar o trabalho pro inferno e vamo acender fogo no fogão e ficar sentado ouvindo a chuva cair no telhado. Que legal! - Ele pegou o canivete do bolso. - Num tenho tempo pra mais. - Ele passou o canivete pela tampa da lata de feijão, retirou o topo e ofereceu a lata a Lennie. Então, abriu uma segunda lata. Do bolso tirou duas colheres e entregou uma para Lennie.

Ambos se sentaram ao lado do fogo, encheram a boca de feijão e mastigavam com vigor. Alguns feijões escapavam pela boca de Lennie. George gesticulou com a colher: Que que vai falar amanhã quando o chefe te perguntar as coisa?

Lennie parou de mastigar e engoliu. Seu rosto mostrava concentração. - Eu ... Eu num vou dizer nenhuma palavra.

- Muito bem! Bom menino! Acho que cê tá melhorando. Quando a gente ter nossas terra vou deixar cê cuidar dos coelho. Se tu lembrar assim direito.

Lennie sentia-se muito orgulhoso. - Consigo lembrar, sim, - exclamou.

George novamente mexeu a colher no ar. - Olha, Lennie. Quero que cê olha bem aqui em volta. Cê consegue lembrar daqui, né? $\mathrm{O}$ rancho é a uns metro daqui pr'aquelas banda. Só seguir o rio.

- Claro, - disse Lennie. - Consigo lembrar. Num lembrei que num vou falar nada?

- Lembrou, sim. Bom, olha, Lennie, se acontecer de tu ter problema que nem cê sempre fez antes, quero que cê vem pra cá e se esconde nos arbusto.

- Esconder nos arbusto, - repetiu Lennie bem devagar.

- Se esconde nos arbusto até eu vim buscar você. Consegue lembrar disso? 
- Claro que consigo, George. Esconder nos arbusto até você vim.

- Mas cê num vai se meter em encrenca, porque se tu fizer isso eu num deixo cê cuidar dos coelho.

Ele atirou a lata de feijão vazia nos arbustos.

- Num vou me meter em encrenca, George. Num vou dizer uma palavra.

- Tá. Traz sua troxa aqui perto do fogo. Vai ser gostoso dormir aqui. Olhando pro céu e pras folha. Num faz mais fogo. Deixa esse apagar.

Fizeram as camas sobre a areia e conforme a chama saía do fogo, a esfera de luz diminuía. Os gravetos curvados desapareciam e somente um tímido cintilar ainda aparecia onde os galhos das árvores estavam. Da escuridão Lennie chamou George: - George, cê já dormiu?

- Não. Que cê quer?

- Vamos ter coelho colorido, George.

- Vamos, claro, - respondeu George sonolento. - Coelho vermelho e cinza e verde, Lennie. Muito coelho.

- Peludos, George, que nem ó, eu vi lá na feira em Sacramento.

- Ah, claro, peludo.

- Por que eu posso muito bem ir embora, George, e morar numa toca.

- Cê pode muito bem ir pro inferno, - disse George. - Cala a boca agora.

A luz avermelhada do fogo morria. Nas colinas em redor do rio um coiote uivava e um cachorro respondia do outro lado da margem. As folhas dos sicômoros murmuravam na leve brisa da noite. 


\section{Of Mice and Men}

A few miles South of Soledad, the Salinas River drops in close to the hillside bank and runs deep and green. The water is warm too, for it has slipped twinkling over the yellow sands in the sunlight before reaching the narrow pool. On one side of the river the golden foothill slopes curve up to the strong and rocky Gabilan mountains, but on the valley side the water is lined with trees - willows fresh and green with every spring, carrying in their lower leaf junctures the debris of the winter's flooding; and sycamores with mottled, white, recumbent limbs and branches that arch over the pool. On the sandy bank under the trees the leaves lie deep and so crisp that a lizard makes a great skittering if he runs among them. Rabbits come out of the brush to sit on the sand in the evening, and the damp flats are covered with the night tracks of 'coons, and with the spread pads of dogs from the ranches, and with the split-wedge tracks of deer that come to drink in the dark.

There is a path through the willows and among the sycamores, a path beaten hard by boys coming down from the ranches to swim in the deep pool, and beaten hard by tramps who come wearily down from the highway in the evening to jungle-up near water. In front of the low horizontal limb of a giant sycamore there is an ash pile made by many fires; the limb is worn smooth by men who have sat on it.

Evening of a hot day started the little wind to moving among the leaves. The shade climbed up the hills toward the top. On the sand banks the rabbits sat as quietly as little gray, sculptures stones. And then from the direction of the state highway came the sound of footsteps on crisp sycamore leaves. The rabbits hurried noiselessly for cover. A stilted heron labored up into the air and pounded down river. For a moment the place was lifeless, and then two men emerged from the path and came into the opening by the green pool.

They had walked in the single file down the path, and even in the open one stayed behind the other. Both were dressed in denim trousers and in denim coats with brass buttons. Both wore black, shapeless hats and both carried tight blanket rolls slung over their shoulders. The first man was small and quick, dark of face, with restless eyes and sharp, strong features. Every part of him was defined: small, strong hands, slender arms, a thin and bony nose. Behind him walked his opposite, a huge man, shapeless of face, with large, pale eyes, with wide, sloping shoulders; and he walked heavily, dragging his feet a little, the way a bear drags his paws. His arms did not swing at his sides, but hung loosely.

The first man stopped short in the clearing, and the follower nearly ran over him. He took off his hat and wiped the sweat-band with his forefinger and snapped the moisture off. His huge companion dropped his blanket and flung himself down and drank from the surface of the green pool; drank with long gulps, snorting into the water like a horse. The small man stepped nervously beside him.

“Lennie!” he said sharply. "Lennie, for God' sakes don't drink so much.” Lennie continued to snort into the pool. The small man leaned over and shook him by the shoulder. "Lennie. You gonna be sick like you was last night." 
Lennie dipped his whole head under, hat and all, and then he sat up on the bank and his hat dripped down on his blue coat and ran down his back. "Tha's good," he said. "You drink some, George. You take a good big drink." He smiled happily.

George unslung his bindle and dropped it gently on the bank. "I ain't sure it's good water," he said. "Looks kinda scummy."

Lennie dabbed his big paw in the water and wiggled his fingers so the water arose in little splashes; rings widened across the pool to the other side and came back again. Lennie watched them go. "Look, George. Look what I done."

George knelt beside the pool and drank from his hand with quick scoops. "Tastes all right," he admitted. "Don't really seem to be running, though. You never oughta drink water when it ain't running, Lennie," he said hopelessly. "You'd drink out of a gutter if you was thirsty." He threw a scoop of water into his face and rubbed it about with his hand, under his chin and around the back of his neck. Then he replaced his hat, pushed himself back from the river, drew up his knees, and embraced them. Lennie, who had been watching, imitated George exactly. He pushed himself back, drew up his knees, embraced them, looked over to George to see whether he had it just right. He pulled his hat down a little more over his eyes, the way George's hat was.

George stared morosely at the water. The rims of his eyes were red with sun glare. He said angrily, "We could just as well of rode clear to the ranch if that bastard bus driver knew what he was talkin' about. 'Jes' a little stretch down the highway', he says. 'Jes' a little stretch.' God damn near four miles, that's what it was! Didn't wanta stop at the ranch gate, that's what. Too God damn lazy to pull up. Wonder he isn't too damn good to stop in Soledad at all. Kicks us out and says, 'Jes' a little stretch down the road.' I bet it was more than four miles. Damn hot day."

Lennie looked timidly over to him. "George?"

"Yeah, what ya want?"

"Where we goin', George?”

The little man jerked down the brim of his hat and scowled over at Lennie. "So you forgot that awready, did you? I gotta tell you again, do I? Jesus Christ, you're a crazy bastard!"

"I forgot," Lennie said softly. "I tried not to forget. Honest to God I did, George."

“O.K.-O.K. I'll tell ya again. I ain't got nothing to do. Might jus' as well spen' all my time tellin' you things and then you forget 'em, and I tell you again."

"Tried and tried," said Lennie, "but it didn't do no good. I remember about the rabbits, George."

"The hell with the rabbits. That's all you ever can remember is them rabbits. O.K. Now you listen and this time you got to remember so we don't get in no trouble. You remember settin' in that gutter on Howard street and watchin' that blackboard?"

Lennie's face broke into a delighted smile. "Why sure, George, I remember that ... but ... what'd we do then? I remember some girls come by and you says ... you say ..." 
“The hell with what I says. You remember about us goin' into Murray and Ready's, and they give us work cards and bus tickets?"

"Oh, sure, George. I remember that now." His hands went quickly into his side coat pockets. He said gently, “George ... I ain't got mine. I musta lost it.” He looked down at the ground in despair.

"You never had none, you crazy bastard. I got both of 'em here. Think I'd let you carry your own work card?"

Lennie grinned with relief. "I ... I thought I put it in my side pocket." His hand went into the pocket again.

George looked sharply at him. "What'd you take outta that pocket?"

"Ain't a thing in my pocket," Lennie said cleverly.

"I know there ain't. You got it in your hand. What you got in your hand - hidin' it?"

"I ain't got nothin', George. Honest."

"Come on, give it here."

Lennie held his closed hand away from George’s direction. "It's on'y a mouse, George."

"A mouse? A live mouse?" dead."

"Uh-uh. Jus' a dead mouse, George. I didn't kill it. Honest" I found it. I found it

"Give it here!" said George.

"Aw, leave me have it, George."

"Give it here!"

Lennie's closed hand slowly obeyed. George took the mouse and threw it across the pool to the other side, among the brush. "What you want of a dead mouse, anyways?"

"I could pet it with my thumb while we walked along," said Lennie.

"Well, you ain't petting no mice while you walk with me. You remember where we're goin' now?"

Lennie looked startled and then in embarrassment hid his face against his knees. "I forgot again."

"Jesus Christ," George said resignedly. "Well-look, we're gonna work on a ranch like the one we come from up north."

"Up north?"

"In Weed."

"Oh, sure. I remember. In Wed."

“That ranch we're goin' to is right down there about a quarter mile. We're gonna go in an' see the boss. Now, look-I'll give him the work tickets, but you ain't gonna say a word. You jus' stand there and don't say nothing. If he finds out what a crazy bastard you are, we won't get no job, but if he sees ya work before he hears ya talk, we're set. Ya got that?" 
"Sure, George. Sure I got it."

"O.K. Now when we go in to see the boss, what you gonna do?"

"I ... I," Lennie thought. His face grew tight with thought. "I ... ain't gonna say nothin'. Jus' gonna stan' there.”

"Good boy. That's swell. You say that over two, three times so you sure won't forget it."

Lennie droned to himself softly, "I ain't gonna say nothin' ... I ain't gonna say nothin'... I ain't gonna say nothin'."

“O.K.,” said George. “An' you ain't gonna do no bad things like you done in Weed, neither."

Lennie looked puzzled. "Like I done in Weed?"

“Oh, so ya forgot that too, did ya?” Well, I ain't gonna remind ya, fear ya do it again."

A light of understanding broke on Lennie's face. "They run us outta Weed," he exploded triumphantly.

"Run us out, hell”, said George disgustedly. "We run. They was lookin' for us, but they didn't catch us."

Lennie giggled happily. "I didn't' forget that, you bet."

George lay back on the sand and crossed his hands under his head, and Lennie imitated him, raising his head to see whether he were doing it right. "God, you're a lot of trouble," said George. "I could get along so easy and so nice if I didn't have you on my tail, I could live so easy and maybe have a girl."

For a moment Lennie lay quiet, and then he said hopefully, "We gonna work on a ranch, George."

"Awright. You got that. But we're gonna sleep here because I got a reason."

The day was going fast now. Only the tops of the Gabilan mountains flamed with the light of the sun that had gone from the valley. A water snake slipped along on the pool, its head held up like a little periscope. The reeds jerked slightly in the current. Far off toward the highway a man shouted something, and another man shouted back. The sycamore limbs rustled under a little wind that died immediately.

“George - why ain't we going' on to the ranch and get some supper? They got supper at the ranch."

George rolled on his side. "No reason at all for you. I like it here. Tomorra we're gonna go to work. I seen thrashin' machines on the way down. That means we'll be bucking grain bags, bustin' a gut. Tonight I'm gonna lay right here and look up. I like it."

Lennie got up on his knees and looked down at George. "Ain't we gonna have no supper?"

"Sure we are, if you gather up some dead willow sticks. I got three cans of beans in my bindle. You get a fire ready. I'll give you a match when you get the sticks together. Then we'll heat the beans and have supper." 
Lennie said, "I like beans with ketchup."

'Well, we ain't get no ketchup. You go get wood. An' don't you fool around. It'll be dark before long."

Lennie lumbered to his feet and disappeared in the brush. George lay where he was and wished softly to himself. There were sounds of splashings down the river in the direction Lennie had taken. George stopped whistling and listened.

"Poor bastard," he said softly, and then went on whistling again.

In a moment Lennie came crashing back through the brush. He carried one small willow stick in his hand. George sat up. "Awright," he said brusquely. "Gi'me that mouse!"

But Lennie made an elaborate pantomime of innocence. "What mouse, George? I ain't got no mouse."

George held out his hand. "Come on. Give it to me. You ain't puttin' nothing over."

Lennie hesitated, backed away, looked wildly at the brush line as though he contemplated running for his freedom. George said coldly, "You gonna give me that mouse or do I have to sock you?"

"Give you what, George?"

"You know God damn well what. I want that mouse."

Lennie reluctantly reached into his pocket. His voice broke a little. "I don't know why I can't keep it. It ain't nobody's mouse. I didn't steal it. I found it lyin' right beside the road."

George's hand remained outstretched imperiously. Slowly, like a terrier who doesn't want to bring a ball to its master, Lennie approached, drew back, approached again. George snapped his fingers sharply, and at the sound Lennie laid the mouse in his hand.

“I wasn't doin' nothing bad with it, George. Jus' strokin' it."

George stood up and threw the mouse as far as he could into the darkening brush, and then he stepped to the pool and washed his hands. "You crazy fool. Don't you think I could see your feet was wet where you went across the river to get it?" He heard Lennie's whimpering cry and wheeled about. "Blublerin' like a baby! Jesus Christ! A big guy like you." Lennie's lip quivered and tears started in his eyes. "Aw, Lennie!" George put his hand on Lennie's shoulder. 'I ain't takin' it away jus' for meanness. That mouse ain't fresh, Lennie; and besides, you've broke it pettin' it. You get another mouse that's fresh and I'll let you keep it a little while."

Lennie sat down on the ground and hung his head dejectedly. "I don't know where there is no other mouse. I remember a lady used to give 'em to me-ever' one she got. But that lady ain't here."

George scoffed. "Lady, huh? Don't even remember who that lady was. That was your own Aunt Clara. An' she stopped givin' ‘em to ya. You always killed 'em.”

Lennie looked sadly up at him. "They was so little," he said, apologetically. "I'd pet 'em, and pretty soon they bit my fingers and I pinched their heads a little and then they was dead-because they was so little." 
"I wish we'd get the rabbits pretty soon, George. They ain't so little."

“The hell with the rabbits. An' you ain't to be trusted with no live mouse. Your Aunt Clara give you a rubber mouse and you wouldn't have nothing to do with it."

"It wasn't no good to pet," said Lennie.

The flame of the sunset lifted from the mountaintops and dusk came into the valley, and a half darkness came in among the willows and the sycamores. A big carp rose to the surface of the pool, gulped air and then sank mysteriously into the dark water again, leaving widening rings on the water. Overhead the leaves whisked again and little puffs of willow cotton blew down and landed on the pool's surface.

"You gonna get that wood?" George demanded. "There's plenty right up against the back of that sycamore. Floodwater wood. Now you get it."

Lennie went behind the tree and brought out a litter of dried leaves and twigs. He threw them in a heap on the old ash pile and went back for more and more. It was almost night now. A dove's wings whistled over the water. George walked to the fire pile and lighted the dry leaves. The flame cracked up among the twigs and fell to work. George undid his bindle and brought out three cans of beans. He stood them about the fire, close in against the blaze, but not quite touching the flame.

"There's enough beans for four men," George said.

Lennie watched him from over the fire. He said patiently, "I like 'em with ketchup."

“Well, we ain't got any," George exploded. "Whatever we ain't got, that's what you want. God a'mighty, if I was alone I could live so easy. I could go get a job an' work, an’ no trouble. No mess at all, and when the end of the month come I could take my fifty bucks and go into town and get whatever I want. Why, I could stay in a cat house all night. I could eat any place I want, hotel or any place, and order any damn thing I could think of. An' I could do all that every damn month. Get a gallon of whisky, or set in a pool room and play cards or shoot pool." Lennie knelt and looked over the fire at the angry George. And Lennie's face was drawn with terror. "An' whatta I got," George went on furiously. 'I got you! You can't keep a job and you lose me ever' job I get. Jus' keep me shovin' all over the country all the time. An' that ain't the worst. You get in trouble. You do bad things and I got to get you out." His voice rose nearly to a shout. "You crazy son-of-a-bitch. You keep me in hot water all the time." He took on the elaborate manner of little girls when they are mimicking one another. 'Jus' wanted to feel that girl's dress-jus' wanted to pet it like it was a mouse-Well, how the hell did she know you jus' wanted to feel her dress? She jerks back and you hold on like it was a mouse. She yells and we got to hide in a irrigation ditch all day with guys lookin' for us, and we got to sneak out in the dark and get outta the country. All the time somethin' like that-all the time. I wisht I could put you in a cage with about a million mice an' let you have fun." His anger left him suddenly. He looked across the fire at Lennie's anguished face, and then he looked ashamedly at the flames.

It was quite dark now, but the fire lighted the trunks of the trees and the curving branches overhead. Lennie crawled slowly and cautiously around the fire until he was close 
to George. He sat back on his heels. George turned the bean cans so that another side faced the fire. He pretended to be unaware of Lennie so close beside him.

"George", very softly. No answer. "George!"

"Whatta you want?"

“I was only folin', George. I don't want no ketchup. I wouldn't eat no ketchup if it was right here beside me."

"If it was here, you could have some."

“But I wouldn't eat none, George. I'd leave it all for you. You could cover your beans with it and I wouldn't touch none of it."

George still stared morosely at the fire. "When I think of the swell time I could have without you, I go nuts. I never get no peace."

Lennie still knelt. He looked off into the darkness across the river. "George, you want I should go away and leave you alone?"

"Where the hell could you go?"

"Well, I could. I could go off in the hills there. Some place I'd find a cave."

"Yeah? How'd you eat. You ain't got sense enough to find nothing to eat."

"I'd find things, George. I don't need no nice food with ketchup. I'd lay out in the sun and nobody'd hurt me. An' if I'd foun' a mouse, I could keep it. Nobody'd take it away from me."

George looked quickly and searchingly at him. "I been mean, ain't I?"

"If you don't want me I can go off in the hills an' find a cave. I can go away any time."

“No-look! I was jus' foolin', Lennie. 'Cause I want you to stay with me. Trouble with mice is you always kill 'em." He paused. "Tell you what I'll do, Lennie. First chance I get I'll give you a pup. Maybe you wouldn't kill it. That'd be better than mice. And you could pet it harder."

Lennie avoided the bait. He had sensed his advantage. "If you don't want me, you only jus' got to say so, and I'll go off in those hills right there-right up in those hills and live by myself. An' I won't get no mice stole from me.”

George said, "I want you to stay with me, Lennie. Jesus Christ, somebody'd shoot you for a coyote if you was by yourself. No, you stay with me. Your Aunt Clara wouldn't like you running off by yourself, even if she is dead."

Lennie spoke craftily, "Tell me-like you done before."

"Tell you what?"

"About the rabbits."

George snapped, "You ain't gonna put nothing over on me."

Lennie pleaded, "Come on, George. Tell me. Please, George. Like you done before."

'You get a kick outta that, don't you? Awright, I'll tell you, and then we'll eat our supper ..." 
George's voice became deeper. He repeated his words rhythmically as though he had said them many times before. "Guys like us, that work on ranches, are the loneliest guys in the world. They got no family. They don't belong no place. They come to a ranch an' work up a stake and then they go inta town and blow their stake, and the first thing you know they're poundin' their tail on some other ranch. They ain't got nothing to look ahead to."

Lennie was delighted. "That's it-that's it. Now tell how it is with us."

George went on. "With us it ain't like that. We got a future. We got somebody to talk to that gives a damn about us. We don't have to sit in no bar room blowin' in our jack jus' because we got no place else to go. If them other guys gets in jail they can rot for all anybody gives a damn. But not us."

Lennie broke in. 'But not us! An' why? Because ... because I got you to look after me, and you got me to look after you, and that's why." He laughed delightedly. "Go on now, George!"

"You got it by heart. You can do it yourself."

"No, you. I forget some a' the things. Tell about how it's gonna be."

"O.K. Someday-we're gonna get the jack together and we're gonna have a little house and a couple of acres an' a cow and some pigs and-"

“An' live off the fatta the lan', "Lennie shouted. “An' have rabbits. Go on, George! Tell about what we're gonna have in the garden and about the rabbits in the cages and about the rain in the winter and the stove, and how thick the cream is on the milk like you can hardly cut it. Tell about that, George."

"Why'n't you do it yourself? You know all of it."

"No ... you tell it. It ain't the same if I tell it. Go on ... George. How I get to tend the rabbits."

"Well", said George, "we'll have a big vegetable patch and a rabbit hutch and chickens. And when it rains in the winter, we'll just say the hell with goin' to work, and we'll build up a fire in the stove and set around it an' listen to the rain comin' down on the roof-Nuts!" He took out his pocket knife. "I ain't got time for no more." He drove his knife through the top of one of the bean cans, sawed out the top and passed the can to Lennie. Then he opened a second can. From his side pocket he brought out two spoons and passed one of them to Lennie.

They sat by the fire and filled their mouths with beans and chewed mightily. A few beans slipped out of the side of Lennie's mouth. George gestured with his spoon. "What you gonna say tomorrow when the boss asks you questions?”

Lennie stopped chewing and swallowed. His face was concentrated. "I ... I ain't gonna ... say a word."

“Good boy! That's fine, Lennie! Maybe you're gettin' better. When we get the coupla acres I can let you tend the rabbits all right. 'Specially if you remember as good as that."

Lennie choked with pride. "I can remember," he said. 
George motioned with his spoon again. "Look, Lennie. I want you to look around here. You can remember this place, can't you? 'The ranch is about a quarter mile up that away. Just follow the river?" say a word?"

"Sure", said Lennie. "I can remember this. Didn't I remember about not gonna

“'Course you did. Well, look. Lennie-if jus' happen to get in trouble like you always done before, I want you to come right here an' hide in the brush."

"Hide in the brush," said Lennie slowly.

"Hide in the brush till come for you. Can you remember that?"

"Sure I can, George. Hide in the brush till you come."

"But you ain't gonna get in no trouble, because if you do, I won't let you tend the rabbits." He threw his empty bean can off into the brush.

"I won't get in no trouble, George. I ain't gonna say a word."

“O.K. Bring your bindle over here by the fire. It's gonna be nice slepin' here. Lookin' up, and the leaves. Don't build up no more fire. We'll let her die down."

They made their beds on the sand, and as the blaze dropped from the fire the sphere of light grew smaller; the curling branches disappeared and only a faint glimmer showed where the tree trunks were. From the darkness Lennie called, "George - you asleep?"

"No. Whatta you want?"

"Let's have different color rabbits, George."

"Sure we will," George said sleepily. "Red and blue and green rabbits, Lennie. Millions of 'em."

"Furry ones, George, like I seen in the fair in Sacramento."

"Sure, furry ones."

"Cause I can jus' as well go away, George, an' live in a cave."

"You can jus' as well go to hell," said George. "Shut up now."

The red light dimmed on the coals. Up the hill from the river a coyote yammered, and a dog answered from the other side of the stream. The sycamore leaves whispered in a little night breeze. 


\section{Nota do tradutor}

John Steinbeck recebeu o prêmio Nobel de literatura em 1962, mesmo sendo o conjunto de sua obra pouco valorizado em seu país natal, os Estados Unidos da América. Dono de uma prosa idílica e poética, escreveu bastante sobre a luta - especialmente dos mais desprovidos - pela sobrevivência. Em grande parte de suas obras, a voz poética, sensível e normativa do narrador contrasta imensamente com a voz realista, rude e não normativa das personagens, como por exemplo em Of Mice and Men. Um dos grandes desafios tradutórios nesse sentido é manter de forma verossímil e não caricata as marcas de oralidade presentes no texto de forma a tentar obter junto ao leitor do texto traduzido efeito de sentido semelhante ao, provavelmente, obtido junto ao leitor do texto de origem.

Neste excerto aparecem duas vozes distintas: a do narrador, em norma culta padrão, e a dos personagens, Lennie e George, com marcas de oralidade, muitas vezes com marcação gráfica de ortografia que foge à norma culta padrão em inglês e outras vezes marcada pelo uso de sintaxe também fora da norma culta padrão do inglês norte-americano. Optamos, então, por traduzir as marcas de oralidade de forma a manter a verossimilhança com o uso do português brasileiro, mais especificamente o uso oral e cotidiano da língua pelo falante brasileiro, da mesma forma com que o autor do texto de origem concebeu as falas dos personagens, ou seja, refletindo a forma com que os norte-americanos também usam a linguagem oral. Entre exemplos desse uso destaca-se a fala de George "I ain't sure it's good water," he said. "Looks kinda scummy.", em que aparecem a forma negativa ain't, considerada não normativa pela língua inglesa padrão, no entanto "aceita em contextos extremamente informais e de preferência oral" (KFOURI, 2020), e conforme explicam Swan (1995, p. 134) “em inglês não-padrão, ain't (...) é usado como contração de am not, are not, is not, have not e has not", e ainda Swan e Walter (2016, p. 9) dizendo que ain't "é muito comum em vários dialetos em inglês". Além disso, nessa mesma fala há ocorrência de linguagem oral informal em inglês empregada pelo autor do texto fonte em kinda, na qual há a "junção de substantivo (...) com a preposição of " (kind of) (KFOURI, 2020). Nesse sentido, foi empregado o recurso do Eye Dialect (BRET'T, 2017) na grafia do texto em português brasileiro, como aparece nos exemplos "Pro inferno c'os coelho" e "Olha, George, olha o qu'eu fiz." Ainda nessa mesma fala de George, ocorre a elipse do sujeito em "Looks kinda scummy", onde a forma normativa do inglês pede "It looks". No entanto, tal uso não normativo da elipse do sujeito não implica uso não normativo no português, portanto temos uma perda aqui, que foi compensada com o uso do advérbio "meia" em Looks kinda scummy sendo traduzido por "Parece meia 
espumosa". Recorremos também ao uso não normativo de sintaxe para marcar o discurso dos personagens, tais como pronomes pessoais "cê", "cêis", "a gente", "tu" concordando ou não com o verbo (Eu tenho as duas aqui comigo. Cê acha que eu ia te deixar cê carregar tua cartera?, para traduzir a fala de George "I got both of 'em here. Think I'd let you carry your own work card?') além da mistura nas falas entre os pronomes "tu" e "você" concordando ou não com o verbo. Vale notar que I got both of 'em here. contém elipse do verbo have (I have got) além da marcação em of ' $\mathrm{em}$, que se perderam na tradução "Eu tenho as duas aqui comigo.", mas que de certa forma foram compensadas no restante da tradução da fala com o uso de "cê" (você) e "cartera" (carteira). Além disso há a não concordância em número (Eu lembro tudo dos coelho, George.), que é estratégia também de compensação, principalmente se considerarmos que essa fala no texto original não há a não concordância de número entre o artigo e o objeto (I remember about the rabbits, George."). Destacam-se também o uso do subjuntivo que foge à norma culta padrão do português brasileiro (Cê ia até beber água de sarjeta se tava cum sede), o uso de "que nem" ou "que nem ó" (Cê vai ficar doente que nem ficou ontem de noite), por exemplo, para comparações ou exemplificações que são algumas das marcas do uso oral, cotidiano e informal da língua portuguesa falada no Brasil. Tais ocorrências trouxeram de forma satisfatória e razoável a verossimilhança almejada, sem, no entanto, caricaturar o texto escrito com demasiadas acentuações gráficas, procurando apresentar os "tipos de marcas" discutidas por Paulo Henriques Britto (2020): "fonéticas, lexicais e morfossintáticas".

Acreditamos que o tradutor mereça ter a liberdade de tratar o texto fonte da forma que melhor lhe convenha. Aqui tentamos aproximar o texto fonte do leitor alvo de forma semelhante com que o autor o concebeu. Além disso, de modo geral, também optamos por um texto no qual tentamos conservar o sabor do estrangeiro, pensando em Venuti (2002). Nesse sentido optamos por traduzir ranch por "rancho" e não "fazenda", denim trousers por "calças rancheiras" que não são exatamente o que falamos no Brasil atualmente, sendo uma forma datada de referência a calças jeans, além da não conversão para quilômetros da medida usada no texto original miles, optando pelo termo "milha", que é, de certa forma, conhecida no Brasil por aqueles que têm a oportunidade de viajar de avião, por exemplo; e ainda mantivemos ketchup, uma vez que esse produto é comumente encontrado no Brasil. Ainda vale ressaltar que buscamos negociar com o leitor do texto traduzido o que informar com naturalidade para dizer 'quase a mesma coisa', remetendo a Eco (2007), como por exemplo a tradução de That ranch we're goin' to is right down there about a quarter mile por "Esse rancho que a gente tá indo é logo ali uns metro", momento em que apesar da opção pelo tom estrangeiro, 
escolhemos "uns metro" acreditando que "um quarto de milha" pouco significaria para o leitor brasileiro, que, neste momento preciso, quer ter uma noção de distância. Algumas perdas no entanto, são irremediáveis, como por exemplo "fogo" que aparece como feminino her no texto de origem em "Don't build up no more fire. We'll let her die down". Acabamos por perder a referência, pois fogo em português remete ao masculino. Na tradução optamos pelo próprio vocábulo "fogo" e o pronome "esse" em "Num faz mais fogo. Deixa esse apagar".

De modo geral, o resultado foi satisfatório para o que propusemos neste trabalho desenvolver, ou seja, trazer a oralidade presente na novela de Steinbeck para o português brasileiro de forma a não sobrecarregar ou caricaturar o texto alvo.

\section{Referências bibliográficas}

BRETT, David. Eye Dialect: Translating the Untranslatable. AnnalSS 6, 2009. Lost in Translation. Testi e culture allo specchio. Disponível em http://www.academia.edu/772710/ Eye Dialect Translating the Untranslatable. Acesso em 30.11.2017.

BRITTO, Paulo Henriques. A tradução literária. Rio de Janeiro: Civilização Brasileira, 2020.

CAMPOS, Odette G. L. A. de Souza et al. "Flexão Nominal: Indicação de Pluralidade no Sintagma Nominal”. In ILARI, Rodolfo (Org.). Gramática do Português Falado - Vol. II: Níveis de Análise Linguística. 3 ed. Campinas: Editora da Unicamp, 1996.

ECO, Umberto. Quase a mesma coisa - Experiências de tradução. Tradução de Eliana Aguiar. Rio de Janeiro e São Paulo: Editora Record, 2007.

GALEMBECK, Paulo de Tarso. "O emprego do subjuntivo e de formas alternativas na fala culta”. In PRETI, Dino (Org.). Estudos de Língua Falada - variações e confrontos. São Paulo: Associação Editorial Humanitas, 2006.

KFOURI, Ana Lúcia da Silva. "What mouse, George? I ain't got no mouse": traduzindo marcas de oralidade em Of Mice and Men de John Steinbeck. 2020. $152 \mathrm{f}$. Dissertação (Mestrado) - Faculdade de Filosofia, Letras e Ciência Humanas, Universidade de São Paulo, SP, 2020.

KOCH, Ingedore. Villaça. "Especificidade do texto falado". In JUBRAN, Clélia Spinardi (Org.). Gramática do Português Culto Falado no Brasil. Volume I. A Construção do Texto Falado. Ataliba T. de Castilho (Coord.). São Paulo: Editora Contexto, 2015.

LEITE, Marli Quadros. "Língua Falada: uso e Norma”. In PRETI, Dino (Org.) Estudos de Língua Falada. Variações e Confronto. 3 ed. São Paulo: Associação editorial Humanitas, 2006. 
SCHERRE, M.; DIAS, E. P.; ANDRADE, C.; MARTINS, G. F. "Variação dos pronomes "tu" e "você"”. In MARTINS, Marco Antonio e ABRAÇADO, Jussara (Orgs.). Mapeamento sociolinguístico do português brasileiro. São Paulo: Editora Contexto, 2015. SCHLEIERMACHER, Friedrich. "On the Different Methods of Translating". In SCHULTE, Rainer and BIGUENET, John (Ed.). Theories of Translation - An Anthology of Essays from Dryden to Derrida. Translated by Waltraud Bartscht. Chicago and London: The University of Chicago Press, 1992.

STEINBECK, John. Of Mice and Men. London: Penguin, 2006.

SWAN, Michael. Practical English Usage. Oxford: Oxford University Press, 1995.

SWAN, Michael \& WALTER, Catherine. Oxford English Grammar Course - Advanced. Oxford: Oxford University Press, 2016.

VIANNA, Juliana Segadas e LOPES, Céla Regina dos Santos. "Variação dos pronomes "Nós" e "A Gente"”. In MARTINS, Marco Antonio e ABRAÇADO, Jussara (Orgs.). Mapeamento sociolinguístico do português brasileiro. São Paulo: Editora Contexto, 2015. VENUTI, Lawrence. The Translator's Invisibility. London and New York: Routledge, 2002. 